\title{
Hydrological Science and Its Connection to Religion in Ancient Egypt under the Pharaohs
}

\author{
Jonas Eliasson ${ }^{1,2}$ \\ ${ }^{1}$ University of Iceland, Reykjavik, Iceland \\ ${ }^{2}$ Kyoto University (visiting), Kyoto, Japan \\ Email: talis.bachmann@ut.ee
}

Received August $8^{\text {th }}, 2013$; revised September $8^{\text {th }}$, 2013; accepted September $15^{\text {th }}, 2013$

\begin{abstract}
Copyright @ 2013 Jonas Eliasson. This is an open access article distributed under the Creative Commons Attribution License, which permits unrestricted use, distribution, and reproduction in any medium, provided the original work is properly cited.
\end{abstract}

\begin{abstract}
The history of water management in the Fertile Crescent is closely related to the religion. This is most clear in ancient Egypt in pharaonic time. The class of priests serving under the pharaoh had also many other administrative duties, they had good skill in science, collected hydrological and astronomical data and used it to levy taxes and predict the floods that irrigated the arable land. The special hydrological features of the river Nile make it rather predictable in behavior compared to other major rivers of the region. In this social position the priests had great influence and could use it to stop the pharaoh Ikhnaton in his attempt to establish a monotheistic religion by ousting Amon-Ra and replacing him with Aton. Social life was very colorful at pharaohs' court and the various arts and festivals flourished. The most remarkable of these was the Opet festival where pharaoh himself was the leading figure together with the statues of the gods. The festival was to last 10 days and during that time the river Nile was to change color from grayish to reddish and thereby mark the beginning of the life-giving flood and bear witness to the good relations between the king and the divine powers. This kind of event, an annual prayer by the king to the gods for good harvest was well known in many societies, but it shows the remarkable skills of the AmonRa priest that they were ready to predict the onset of the Nile flood within ten days and get away with it.
\end{abstract}

Keywords: Egypt; Religion; Hydrology; Pharaoh; River Nile

\section{Introduction}

When discussing religion in the ancient world, it is necessary to realize that religion, administration and technology could be integrated into a single unit. This article attempts to show how the various natural forces and related technologies were in ancient times believed of divine origin. It is important in this respect, to consider that the attitude of ancient peoples, such as Egyptians to divinity, were significantly different from modern perspectives and are often misunderstood by scholars (Hornung, 1982; Hornung, 1999). Egyptian religion was close to shamanism (Morenz, 1992); as the images of the gods from this period show and taboos were common (Assman, 1992). Natural phenomena were controlled by different deities and survival depended on the Nile floods that occurred around the same time every year, irrigated the land and made it fertile as long as the soil remained moist (White, 2003).

During the flood periods nomadic tribes with their herds migrated into Egypt (White, 2003). Such nomads may still be seen on the move south of Sudan in the vast Sudd swamps that the Nile floods once a year and so the land is covered with vegetation. Thus has the Nile valley been, and here (Biswas, 1970), the human race learned the art of increasing harvest by plowing away the natural vegetation, plant grain, harvest it and live off agriculture. Later they learned also to build irrigation systems and keep flood water for later use (Biswas, 1970; Werner, 1983); but now the Aswan dam has taken over this role. The water management led to the agricultural revolution and it provides the basis for the magnificent civilization of ancient Egypt. Science flourished, the main branch being astronomy and calendar computation, which was theological in character (McClellan \& Dorn 1983). Connections between astronomy, calendar calculus and religion were actually very common until the present day.

Several hazards were threatening the Egyptian nation, enemy invasions; too small floods that led to drought, too big floods on the other hand could be disastrous for people and livestock alike. When everything was well, the population increased to numbers that the arable land could not sustain with famine as the result. Such events were God's punishment, and the only possible remedy was to have a warrior king who could communicate with god and persuade him to protect the nation. From the perspective of the ancient Egyptians the king Pharaoh was needed to ensure fertility, Nile and all life in the country through his capability to communicate directly with god (Shaw, 2000).

Under the pharaoh was the nobility, such as various officers, priests, generals, constructors and regional commanders (BrugschBey, 1996). The purpose of this article is to show how the administration, technology and religion are interwoven in the realm of ancient Egypt; these were all branches on the same trunk, the survival of the nation by the grace of the gods. Scholars of Egyptology are largely interested in Egyptian antiquities and their relationship to the ancient kingdom of the 
Pharaohs. In this article archeology and specific dating are avoided, but when they are mentioned they follow the http:// touregypt.net originally developed in 1994 by the Ministry of Tourism of Egypt, under the direction of Mamdouh al-Beltagi. There are also considerable contributions to Egyptology material on the internet and elsewhere that originates from Zahi Hawass, an Egyptologist, and former Minister of State for Antiquities Affairs in Egypt. Interested readers can find additional information on the: Tour Egypt: http://touregypt.net/ehistory. htm.

Correct dating is difficult in Egyptology, experts agree upon when Alexander the Great was pharaoh, then upon when the Assyrians sacked Thebes about 300 years before, but the rest is a little shaky. Manetho's (Manetho's List, 2012): original list of Egyptian kings and dynasties was never completely accepted and revisions are still being made. As an example (Brugsch-Bey, 1996), means Ikhnaton ascended to the throne 1473 BC but this has now been revised to 1352 BC. Furthermore there is (Newgrosh, Rohl, \& van der Veen, 1993), that in the Journal of Ancient Chronology Forum publish theories that there is communication between the first king of Israel, Saul and Ramses II and possibly Ikhnaton in the Amarna letters, described by (Moran, 1992).

\section{Agriculture Creates Superpowers}

During the first millennia in written history, the northern hemisphere was sparsely populated with nomadic peoples but the populations increased rapidly when their herds grew (Cunliffe, 1997). They migrated from the steppes to the South. Here, conditions for raising livestock were worse, but agricultural conditions better. In the agricultural revolution large societies and culture are created in the floodplains of the large valleys (Brugsch-Bey, 1996; Hurst, 1951), starting around 5000 BC. These were farming communities; the best known sites are along the Indus in India, Yellow River in China, Euphrates and Tigris in Mesopotamia and the Nile in Egypt. All these rivers, flood, irrigate the land and provide opportunities for farming even though rainfall is in very short supply in the farmland itself.

The art of taming the rivers and cultivating the otherwise arid land turned many an ancient nomadic tripe into a superpower. The largest and most influential area was the Fertile Crescent. Apart from the technical and organizational skills that brought us the wonderful pyramids (Hawass \& Lehner, 1997), the Egyptians rose to incredible heights in hydraulic engineering (Kaplan, 2004). The priests operated water level stations, the Nilometers, and built irrigation works (Biswas, 1970), which lead to that the clergy became a very important part of the administration. Divine origin of nature manifested itself in the Pharaonic figure and the River Nile, which brings the water, food and fertility to the nation.

The best conditions for agriculture in the Fertile Crescent were the floodplain around the Nile in Egypt and the floodplain between Euphrates and Tigris in Mesopotamia. All fields are very dry and hot, but the rivers flooded once a year. You can make irrigation, sometimes with little effort, and keep adequate flood water in the irrigation systems after the flood to get one harvest. In this way, the land yields far more food than by cattle herding only. When things are going well the population grows rapidly and powerful kingdoms emerge. Pharaoh's grain stock is growing, pyramids, roads, new dams, canals and locks are built. The best example is the Bahr Yussef canal built around 4300 years ago. It diverts water from the Nile floods into the Fayum (Al Fayyum) oasis near Cairo, doubling the farmland in the oasis and serving as irrigation reservoir.

But floods are not just a blessing. Too large floods damage irrigation works and drown people and livestock. The ancient legend of Noah preserves the story of the flood risk that constantly threatened the civilizations in the Fertile Crescent. The legend is preserved in the Gilgamesh epic from Mesopotamia (Heidel, 1946). It tells the tale of Utnapishtim; he alone survives the great flood. Devastating floods can occur in Mesopotamia if extreme floods hit the big rivers Euphrates and Tigris at the same time. Then the whole valley is flooded, including Ur, the capital of Sumer and the city of Abraham (Werner, 1983). The largest of these floods has left thick sediments of clay in the entire Mesopotamian valley with the exception of the highest hills (Werner, 1983).

When the rain fails the floods can also be too small for the water level to lift itself above the river channel banks and irrigate the land, the canyon in the wall holding the entrance to the Luxor temple (Luxor Temple, 2012) symbolizes this. Then the crop fails with famine as the result, the cause may be many things. Local climatic variations can be everything from unusually small precipitation, to extreme events e.g. global temporary climate change due to volcanic eruption in Iceland (Oman, Robock, Stenchikov, \& Thordarson, 2006). Apart from the disasters coming from the Nile, wars were common; the lower part of Egypt was harassed by constant invasions of the peoples to the north, the Egyptians called them Hyksos. They ruled for some time from their capital city Avaris.

\section{The Rise of Hydrologic Technology and Water Management}

Considerable documentation exists about water management in the Fertile Crescent. It shows a high level of technical and managerial skills. In the city of Mari in Mesopotamia libraries of clay tablets were found that show a map of the fields and irrigation ditches that provide water to them (Biswas, 1970). A similar map of the irrigation systems along the Yellow River in China exist (Biswas, 1970). It took about 500 years to complete the Chinese system, but according to legends it is the work of Emperor Wu of the Western Han dynasty who reigned 206 BC-9 $\mathrm{AD}$. Then are the famous qanat systems in Persia Iran, they are complex system of tunnels that are dug into the mountains to collect groundwater (Biswas, 1970). Such systems could be diverted into cities without any flood risk, for example to the famous Paradiso gardens in ancient Persia. Today the Taj Mahal Palace in India is the best known place with this type of garden architecture.

But the art of water management rose to its highest levels in ancient Egypt. The largest part of it is desert; the country is almost just a green belt around the river Nile. Living conditions are much better than in Mesopotamia, the floods more regular and droughts not so common. The river flows from south to north, the wind blowing from north to south and it almost never rains. The Nile is navigable up to the first cataract at Aswan and ancient Egypt is from here to the sea. South of Egypt was Nubia, where the Egyptian army frequently battled and took slaves. Originally there were two Egyptian states, but they are united in times of the old kingdom (Dunn, 2012). 


\section{Basic Hydrology of the River Nile and the Use of Hydrologic Data in Administration}

The White Nile, flows from the Lake Victoria. This is the largest lake in the world with enormous storage effect so in its beginning the White Nile flows very evenly throughout the year. At Khartoum in Sudan the Blue Nile River, which comes from Lake Tana in Ethiopia joins the White Nile. The Blue Nile is a very small river, except in the monsoon rain season in May and June. Then it rains very heavily on the mountains in Ethiopia and the water flows then from all sides into the Lake Tana, so the Lake Tana River crashes with enormous power down the Nile Waterfalls and further along its channel down to Khartoum. The power of the Blue Nile is so great that it stems the White Nile seriously and helps to fill up the Sudd swamps. But four rapids between Khartoum and Aswan slow the flood down, it takes a few weeks for it to fill the river channel, so the flood did not come to Egypt until July, but then usually lasted for two months. Blue Nile has a reddish color but the White Nile grayish, so the color change of the Nile marks the beginning of the flood. This color change was duly noted in the capital Thebes now Luxor, directly opposite the famous royal graves in the Valley of the Kings.

A part of the flood water was stored up inside the irrigation system. The moist soil was plowed as soon as possible and the irrigation system used for the plants and in March the crops were harvested. The land was mostly owned by nobles and priests, which in turn paid taxes to the king. There was considerable persistence in the floods, "good floods" and "bad floods" respectively, had a tendency to group, like in the biblical legend of the seven fat and seven lean years Genesis 41: 17 - 36. Today persistence and autocorrelation of the floods of the Nile are known from the hydrology research on the two thousand years' time series for the water levels of the Nile gathered by the priests (Biswas, 1970; Hurst, 1951).

There were the priests in the temple Karnack and other temples along the river banks who operated the water level measurements of the Nile. They built water level gauges, called Nilometers (Biswas, 1970). These were deep wells of piled stones with a high column in the center of the well with a scale on it where the water level could be read and recorded. This measurement method is still in used Figure 1.

With the results of the water level recordings and experience over the years it was relatively easy for priests to calculate the harvest and those accounts were used in levying taxes. This is the only known example of priests playing the role of the internal revenue department using water levels as their evidence. But the priests of ancient Egypt had many official functions so this has been as natural a role for them as doing service in the temple. Their role as priests was to serve the gods inside the Holy of Holiest in the temple, e.g. bring them food once a day.

But temple service was only 3 - 4 months a year for the average priest in other times of the year, he was in administration, e.g. the tax collector who visited the farmers with a record of what each had to pay and charged them accordingly. If they did not pay, there was a police force to take care of that matter (Protecting Civilians, 2012).

\section{The Divine Power and the Royal Power}

In ancient Egypt, spiritual and secular authority is one and the same. All natural phenomenon's, the water, the land and the animals were of divine origin and man was too. Top rank was

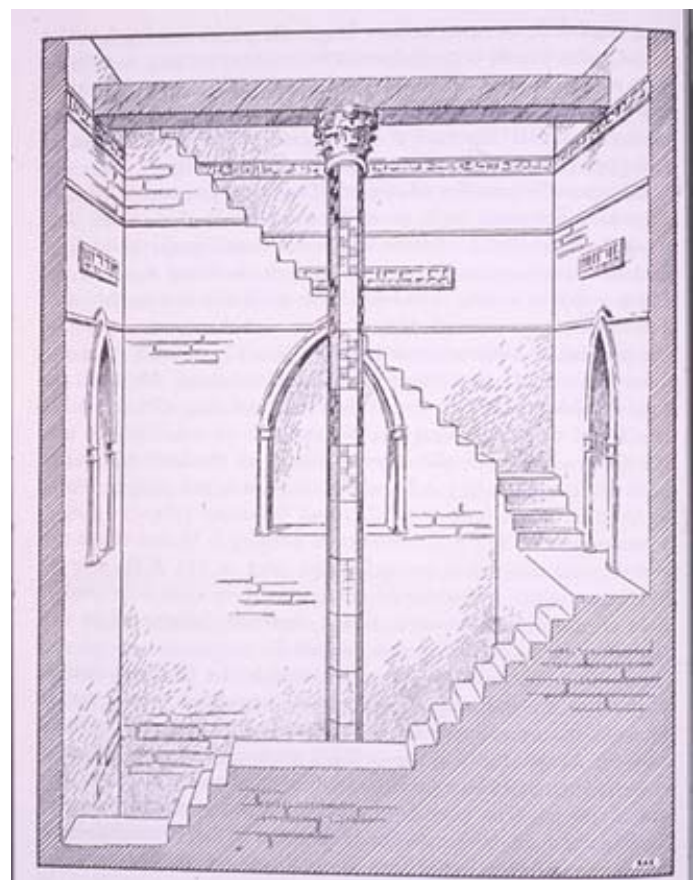

Figure 1.

Nilometer.

the king, the Pharaoh, he descended from the gods but he himself was not a god, even though some past kings did make it to the divine ranks. The most famous of these is Osiris (Morenz, 1992) and his son Horus, whose symbol is the falcon, most sacred of all birds. Egyptian gods were numerous but only 115 are known (Hornung 1982). Many animals like hawks, lions, cats and crocodiles (Dunn 2012) were worshipped. There were gods and goddesses, each could be portrayed with a single icon in the hieroglyphic texts. Sometimes a god appears with the head of an animal, especially the male gods. This animal worship was more practiced in the Fertile Crescent than in the Mediterranean religious systems of the Greeks and the Romans. This suggests that the Egyptian religious system was originally worship of deities in the nature and spirits like in Shamanism, but this does not have to be more than partially correct.

Deities could merge together and change roles, e.g. the sun god Ra sometimes merged with Horus and became Horus-Ra with a human body and a falcon head crowned with a sun-disc. $\mathrm{Ra}$ also merged with Amon to become Amon-Ra, who was a god with a ram head and a sun-disc while Amon himself had a human head.

In Manetho’s list (Manetho’s List, 2012): are 30 Dynasties of Egyptian pharaohs. The rank of the gods varied through the times and there is a possibility that when one king dethroned another and replaced that dynasty with his own, similar revolutions followed in the realm of the gods. As an example, during the eighteenth dynasty 1539-1295 BC Amon-Ra was the supreme god and his power great, but not in the times before and after.

The ancient Egyptians had a great respect for the afterlife and great preparation was needed so the soul of the deceased would receive worthy reception in the realm of the dead. For example, the rite that took place when the heart of the dead were weighed and evaluated before it was accepted. A famous picture from the Book of Dead (Book of Dead, 2013) shows this in Figure 2. 


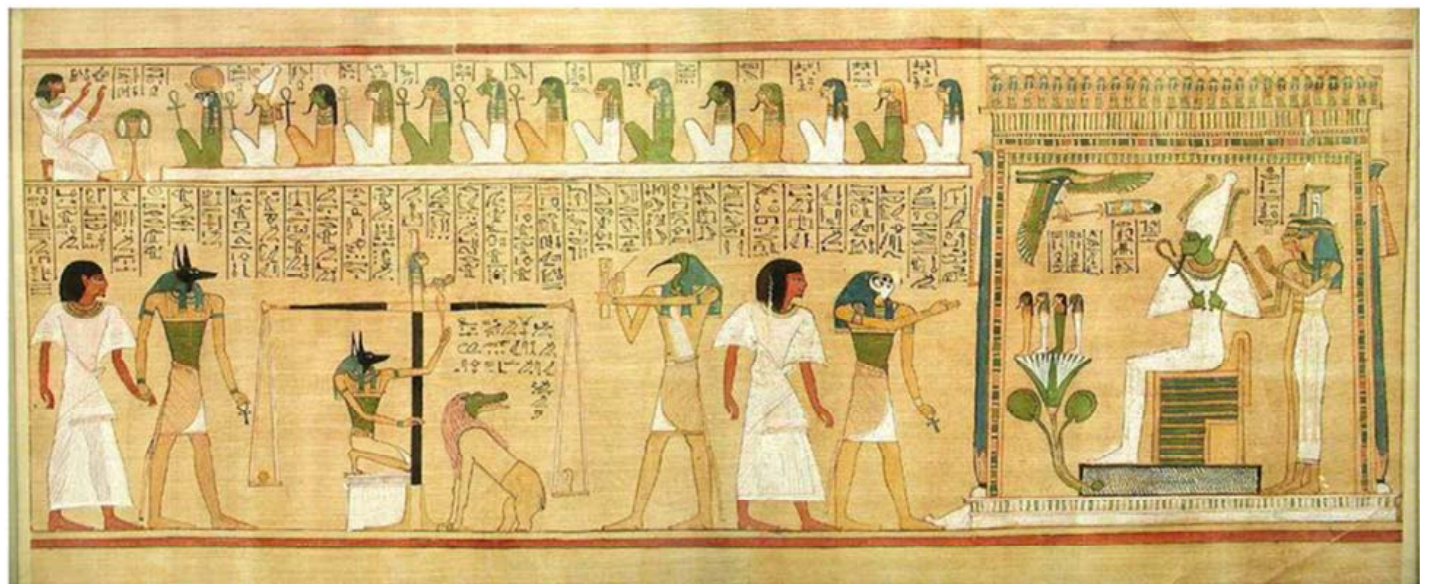

Figure 2.

The heart of a scribe being weighed against the feather of Maat from Book of the Dead.

Anubis comes with the deceased by his hand to the ceremony. This is no coincidence, Anubis was the god of mummification, and his role was to assist the deceased on his journey that was both complex and dangerous. Toth with Ibis head comes with the heart of the deceased and a feather from the hair dress of Maat, the goddess of truth, on a tray. Anubis places the heart and the feather on either side of a scale. But the monsters Ammi, representative of the underworld, watches closely, he gets the soul if the heart does not meet the test. If all goes well Horus son of Osiris, former pharaoh and now god, takes the deceased by the hand and follows him into the Holy of Holies where his father and Isis, his mother, wait. Next to Isis waits Maat, presumably to get her feather back.

\section{The Mystery of Ikhnaton}

Deities could move up and down the ranks with the help of the king, though it probably has happened more frequently, that the Pharaoh came to power with assistance from the gods. A good example of the former is when Amenhotep IV dethroned Amon-Ra, replaced him with the sun-disc god Aton and took the name Ikhnaton for himself. For this he was nicknamed the heretic king, (Brugsch-Bey, 1996). What is striking here is that the new faith was monotheism, the people was to worship only the god Aton, who had a low rank before Ikhnaton's time.

Researchers do not totally agree how Amenhotep IV got this strange idea. According to the Bible, the Hebrew descendants of Joseph and his brothers, which according to biblical legends came to Egypt in the times of the 15 dynasty or about 1650 BC, (Manetho's List, 2012), lived in the country in Ikhnaton's time. Some believe that Joseph was at the court of Ikhnaton's father, even his viceroy (Minister) see Genesis 41: 37 - 41. This has created wild speculations about that Ikhnaton was in his monotheisms under religious influence from the Hebrews. But many modern scholars believe now that the Old Testament's legend of the Hebrews in Egypt is a myth although this is not explicitly stated (Bimson, 1988). The legend may be true never the less. In Egypt, the Hebrews would have been counted in all writing as Hyksos anyway.

Others still take a more practical approach in the Ikhnaton mystery. The Amon priests were very powerful, owned about $1 / 3$ of the land and did not always do pharaohs' bidding. It may be suggested that the king was simply trying a kind of Cultural
Revolution to keep them down in the same way as Mao revolted against his regional commanders in our times. This Ikhnaton did by building in a short time a totally new capital, Akhenaten, which he filled with wonderful works of art in a totally new style. But his administration was not as successful. After his reign 1353-1336 BC (Hornung, 1999); the economy was in total ruin (Akhenaten, 2012). This is understandable as the former administrators, the Amon priests, were totally opposed to Ikhnaton and had every possibility to work against him. Furthermore, a bad infectious disease harassed the country in his time.

Speculations about that Ikhnaton's and Moses' gods were one and the same are very interesting but hardly realistic, (Bimson, 1988). A closer study of these deities shows them very different. That Aton was the lawmaker and supreme judge like Jahve was out of the question, supreme judge was pharaoh. That Jahve should allow brother and sister to wed, as was the custom of Egyptian royalty, no way. Many other arguments can be made.

\section{Arts and Culture at the Court}

Further research may uncover new evidence, but until then there is the Egyptian art and craftsmanship to admire, it rose to incredible heights in technology and design under Ikhnaton's rule so all the world is in great depth to this heretic king. There are also speculations that Ikhnaton's art was influenced by the Hebrews. But Ikhnaton's chief art designer and architect were named Bek and there is no evidence that he was not Egyptian. Among the works created in his time is the fabulous statue of Nefertiti, an exquisite work of art, both in form and classical beauty. The death mask of Tutankhamen (ca. 1333-1322 BC) is also a wonder, it was found in his tomb, along with a number of other artworks. He was probably Ikhnaton's son and in his 10 year's reign as King, began the conversion to the old faith. So the new religion was short-lived and the Amon-Ra priests regained all the former powers that Ikhnaton took from them, which is a remarkable testimony to their cunning.

\section{The Opet Festival}

The Egyptian gentry loved to pass the time in hunting and parties, just like nobility of all times. But everybody had to 
stick to his place. The common farmers spent their life more or less in serfdom and we know little of their lives (Hawass, 1997). But the graves of the nobility are full of paintings with stories of how pharaoh was hunting lions while lesser noblemen were hunting pigs or fishing. On these pictures the rank of persons can be judged, the higher the rank, the bigger is the person's body in the picture.

But sometimes the crowd was allowed to participate in the celebrations, especially when they were designed to show the good relations of the administrators, king and priests, to the gods who ruled over the welfare of the people. The best example is the annual Opet festival held on the Nile. It was very popular during the eighteenth dynasty, so popular was that it could lead to hostilities if it was cancelled (Kruchten, 1991).

The purpose of the festival was a meeting between God and pharaoh, to ensure a good flood, the necessary condition for a good harvest. The king should, in other words ensure fertility of the earth by communicating with the gods, a well-known theme in ancient societies, and more may be remaining of this custom than what is commonly accepted. Statues of Amon-Ra were ferried on the Nile from Thebes to the landing site in front of the big temple Karnack (Leprohon, 1999), and carried from there in a great parade by a road lined with statues into the temple. Detailed description of this parade and associated festivities does not exist, and it may also have changed over the hundreds of years the Opet was held. But there were, however, fixed points. Sailing on the Nile with the statues of the gods was one of them.

Another fixed point was the parade into the temple and the mysterious service in the temple. The service was a most secret event, a meeting between the king and god. We can let Figure 3 represent what happened, even though the picture is from another occasion. There is a man between two gods. His head dress, particularly the Cobra snake figure on the forehead, tells us this is pharaoh himself. On either side of him are Horus and Anubis, guardians of the king and helpers in life and death. They are waiting for the boat at the top right of the image. A closer examination shows that there is Amon-Ra coming, with its ram head symbolizing Amon and crowned with a sun-disc symbolizing Ra. The figure does not leave us in doubt that Pharaoh is a bit nervous, much is at stake that the meeting goes well.

Here we have a ceremony where the king asks the gods to bring the nation her necessities by virtue of their power over the elements (Morenz, 1992). Similar ceremonies were in other communities, the best known the ceremony in the temple of heaven in Beijing where the Emperor prayed for good harvests.

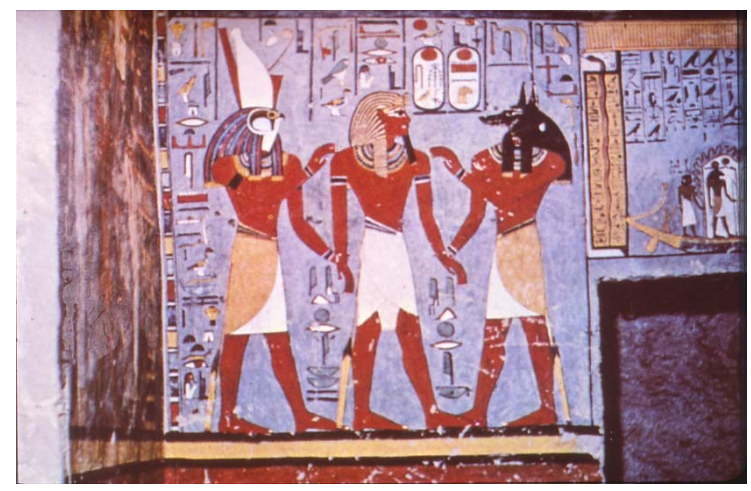

Figure 3.

Pharaoh in the center flanked by Horus left and Anubis right.
We must admire the Amon priests for daring such an act. Besides computational skills and fairly detailed calendar, which they certainly had (Kline, 1972; Morenz, 1992); they had to have a comprehensive knowledge of the behavior of the Nile flood to be able to predict it within 10 days. To this day, such a prediction is still a problem. This festival is perhaps the best example of how religion, government and technical skills were interwoven in this greatest culture of the world during its time.

Today, the same nation is living in Egypt and then. But the floods of the Nile now stop at the Aswan dam and the Nile crocodile downstream of it is dead. He was one of the main animal gods of ancient Egypt, with him went the last living icon of the old time. But the legacy of Egyptian religion and technical skills still survives to this day, the world is in debt to ancient Egypt, it will never be paid in full (Hornung, 1982).

\section{REFERENCES}

Akhenaten (2012). http://en.wikipedia.org/wiki/AkhenatenWikipedia Assman, J. (1992). When justice fails-Jurisdiction and imprecation in Ancient-Egypt and the Near-East. Journal of Egyptian Archaeology, 78, 149-162.

Bimson, J. J. (1988). Exodus and conquest-Myth or reality. Journal of Ancient Chronology Forum, 2, 27-40.

http://www.hope-of-israel.org/conquest.html

Biswas, A. K. (1970). History of hydrology (pp. xii + 336). New York: American Elsevier Publishing Co.

Book of the Dead (2013).

http://en.wikipedia.org/wiki/Book_of_the_Dead

Brugsch-Bey, H. (1996). Egypt under the Pharaos. London: Bracken Books.

Cunliffe, B. (1997). The Oxford illustrated history of prehistoric Europe. Oxford: Oxford University Press.

Dunn, J. (2012).

http://www.touregypt.net/featurestories/animalcults.htm

Hawass, Z. (1997). Tombs of the pyramid builders. Archaeology, 501, 39-43. http://archive.archaeology.org/9701

Hawass, Z., \& Lehner, M. (1997). Builders of the pyramids. Archaeology, 501, 30-46.

http://archive.archaeology.org/9701/abstracts/pyramids.html

Heidel, A. (1946). The Gilgamesh epic and old testament parallels. Chicago: University of Chicago.

Hornung, E. (1982). Conceptions of God in Ancient Egypt: The one and the many (p. 296).

Hornung, E. (1999). History of Ancient Egypt. (Translation of Grundzüge der Ägyptischen Geschichte by David Lorton, Trans. Ithaca). New York: Cornell University Press.

Hurst, H. E. (1951). Long-term storage capacity of reservoirs. Transactions of the American Society of Civil Engineers, 116, 770-799.

Kaplan, L. C. (2004). Technology of Ancient Egypt. New York, NY: Power Kids Press.

Kline, M. (1972). Mathematical thought from ancient to modern times (pp. xvii+1238). New York: Oxford University Press.

Kruchten, J. M. (1991). The year when the opet festival was not held in Paophi. Journal of Egyptian Archaeology, 77, 182-184. doi:10.2307/3821967

Leprohon, R. J. (1999). Reliefs and inscriptions at Luxor Temple, vol. 1, the festival procession of Opet in the Colonnade Hall, with translation of texts. Journal of Near Eastern Studies, 584, 301-303. doi:10.1086/468752

Luxor Temple (2012).

http://en.wikipedia.org/wiki/File:Egypt.LuxorTemple.06.jpg

Manetho's List (2012).

http://en.wikipedia.org/wiki/List_of_pharaohs\#Existing_primary_old _lists_of_pharaohs

McClellan, J. E., \& Dorn, H. (1999). Science and technology in world history, an introduction. Baltimore: The Johns Hopkins University Press. 


\section{J. ELIASSON}

Moran, W. (1992). The Amarna letters. Maryland: The Johns Hopkins University Press.

Morenz, S. (1992). Egyptian religion. Cornell paperbacks. Ithaca: Cornell University Press.

Newgrosh, B., Rohl, D. M., \& van der Veen, P. G. (1993). The elAmarna letters and Israelite history. Journal of Ancient Chronology Forum, 6, 33-64.

http://www.newchronology.org/cgi-bin/somsid.cgi?type=pdf\&page= 06a033\&code=rbhcf1a6\&session=1376973446\&record=78\&subpag $\mathrm{e}=0$ \&hl=The+el-Amarna+letters +

Oman, L., Robock, A., Stenchikov, G. L., \& Thordarson, T. (2006). High-latitude eruptions cast shadow over the African monsoon and the flow of the Nile. Geophysical Research Letters, 33, L18711.
doi:10.1029/2006GL027665

Protecting Civilians (2012)

http://www.reshafim.org.il/ad/egypt/law_and_order/police.htm

Shaw, I. (2000). The Oxford history of Ancient Egypt Oxford illustrated histories. Oxford: Oxford University Press.

Werner, K. (1983). Doubleday books. New York, NY

White, B. L. (2003). Religious foundations of egyptian engineering \& science, Ancient Egypt provides an early example of how a society's worldview drives engineering and the development of science. The Egyptian mind, graduate seminar-Under the direction of Dr. Joseph Manning. Stanford: Stanford University.

http://www.strategic-tech.org/images/Egyptian_Engineering_and_Cu lture.pdf 